【論 文】

UDC : 72.03(52) : 726.134
日本建築学会計画系論文報告集 第 424 号・ 1991 年 6 月 Journal of Archit. Plann. Environ. Engng, AIJ, No. 424, June, 1991

\title{
近世京都日蓮宗立本寺, 妙満寺, 妙蓮寺の伽藍配置 ON THE PLAN OF THE COMPOUND IN RYUHONJI, MYOMANJI AND MYORENJI BELONGING TO NICHIREN SECT AT KYOTO IN MODERN TIMES
}

\author{
丹羽博 亨* \\ Hiroyuki NIWA
}

\begin{abstract}
In this paper, I selected three temples out of 16 head temples of Nichiren sect at kyoto as follows. Those are 1) Ryuhonji where Soshi-Do was disposed facing Kishi-Bojin-Do. (Setsu-Do) in front of Shaka-Do, 2) Myomanji, where Shaka-Do was disposed right-angled to Soshi-Do and 3) Myorenji, where Shaka-Do and Soshi-Do was disposed from east to west facing to the south. Because I'd like to research on the process of changes of principal hall and factors of the disposition of the Buddhisttemples. As the result, substantial three items, which were interpreted in this paper, were clarified.
\end{abstract}

Keywords : plan of compoond, Buddhist temples, Shaka-Do, Soshi-Do, Setsu-Do 配置計画, 仏教寺院, 釈迦堂, 祖師堂, 刹堂

序

櫻井敏雄氏は『鎌倉新仏教仏堂平面の成立と系譜に関 する研究】”「「名所図会等にみられる大寺の伽藍」の 項において，本堂前面に祖師堂と鬼子母神堂 (刹堂) が 軸線をはさんで対峙させる配置として本图寺, 頂妙寺, 立本寺, 本堂と祖師堂を矩の手に配置させた本能寺, 本 法寺, 妙満寺, そして, 本堂亡祖師堂を併置させた本隆 寺, 妙蓮寺があることについて指摘されている。

前稿 ${ }^{2}$ では京都日蓮宗 16 箇本山寺院の内, 妙顥寺に おいては御影堂（祖師堂）が最初に建立され，妙覚寺， 要法寺においては积迦堂よりも御影堂の規模を拡大して いることに言及し,伽藍配置の要因についても考察した。

本稿では京都日蓮宗 16 箇本山寺院の内, 立本寺 (京 都市上京区), 妙満寺 (京都市左京区), 妙蓮寺 (京都市 上京区) をとりあげ，主要堂宇の推移の過程と伽藍配置 の要因について考察する。

\section{1. 文字曼茶羅と伽藍配置の要因}

『法華経見宝塔品』に虚空に宝塔が涌出し，その宝塔 の中に妙法蓮華経を中心に釈尊と多宝仏が左右に坐し， 釈尊の脇士である本化地涌の四大菩薩がひかえ, 迹化と 他方より来た諸菩薩等はずっと下からこれらの菩薩を仰 ぎ見る，いわゆる虚空会の儀式が説かれている。

多宝如来は東方宝净世界に住し, 宝塔は東方宝浄世界
から法華会に来至している。したがって, 虚空会上の宝 塔は西向きとなり，宝塔内の釈尊は北の上座 (右側), 多宝如来は南の下座（左側）に位置する。

日蓮は法華経に説かれている虚空会の図景を借りて具 象化した文字曼荼羅を図顕し, 多くの弟子, 壇越に授与 している。

日蓮書写の文字曼荼羅の立体的配座は, 右側の上座に 釈尊, 左側の下座に多宝の二仏が並座し，この師たる釈 尊, 多宝の二仏に向かっているのが, 弟子たる上行菩薩, 十羅刹女等であるので,この場合は左右の関係が逆とな り, 左側が上座となり, 本化地涌首導の上行菩薩が左側 の上座に勧請されている。

この左右の関係は日我 (1586 殆) の『化儀秘決』に『是 れは何も仏の方より云ふ時の方角なり, 参る人の為には 右は左なり」光之あり, 橎尊, 多宝の二仏の側（正面か ら見た場合）からながめた場合である。

・日朗門流相伝の日経 (1473歾) 記『御本尊口伝面授 私』に「左”ニ御影堂”造中事”忝モ大聖人”其本地”尋中セ” 上行菩薩“テ御座故“本地”文字“約”左“御影”立テ申事モ 有”的)之あり，大聖人（日蓮）の本地を上行菩薩とする 意から,「本地”文字」, すなわち日蓮書写の文字曼荼羅 に約して御影堂（祖師堂）を左側（仏の方より云了時の 方角）に配するとしている。

京都日蓮宗 16 䇢本山寺院の内, 9 箇本山寺院が釈迦

$*$ 広島工業大学工学部建築学科 教授 $\cdot$ 工博 Prof., Dept. of Architecture, Faculty of Engineering Hiroshima Institute of Technology, Dr. Eng. 
堂を右側, 祖師堂を左側（仏の方より云ふ時の方角）に 配している。

しかし, 日蓮㱛後, 日蓮への追慕想起の念が強い寺院 では, 妙覚寺, 要法寺のように釈迦堂より御影堂（祖師 堂) の規模を大きくした本山寺院もあった。そして, 妙 蓮寺と本隆寺の 2 箇本山寺院にあっては, 釈迦堂と御影 堂の配置を前述の 9 箇本山寺院とは逆に配している。

以下, 京都 16 箇本山寺院の内, 3 主要本山寺院の伽 藍配置の要因について考察する。

\section{2. 立本寺における主要堂宇と配置}

立本寺は妙顕寺第 4 代日実 (1378 歿) を開祖とし, 明徳 4 年 (1393) に押小路堀河の西南の地に堂舎を建立 した時を創立としている。

天文 5 年 (1536) の天文法華の乱に上り焼失, 一時堺 へ逃れた後, 天文 13 年 (1544) に新町三条に再興して いる。

文禄年中（1592～96）に京極今出川に移っている ${ }^{5 !}$ 。

『本化別頭仏祖統記』に「寛文元年辛丑立本寺火師 援、之 ${ }^{ }$振 焼失し，第 20 代日審（1666 㱛）の代に大殿（園林堂） が建立され, 延亭年間（1681～83）には祖師堂が建立さ れている7。

京極今出川における伽藍配置は貞亨 3 年 (1686) 刊の 新編法華霊場記』に所収されている立本寺境内景観 ${ }^{8)}$ (図一1)によって知ることができる。

そして, 元禄 15 年 (1702) 脱稿の『山州名跡志』に 門”西向 ${ }^{\text {リ。 }}$

堂`南面 リ。

祖師堂`在”堂’東南三, 西面 ${ }^{\text {。 }}$

十羅刹堂”在尘堂’西南三, 東面 ${ }^{2}$ 。

経蔵”在”三祖師堂”南三, 西面 ${ }^{\text {。 }}$

七面明神'社”在”経蔵'南池'中三, 西面 ${ }^{\text {又 }}$ 。

三十番神'社”在兰仏殿'東三, 西面 ${ }^{29) 。}$

とある。

京極今出川当時は寺地の西側に京極通(現在の寺町通) に向かって表門が設けられ，釈迦堂は南面し，その前方

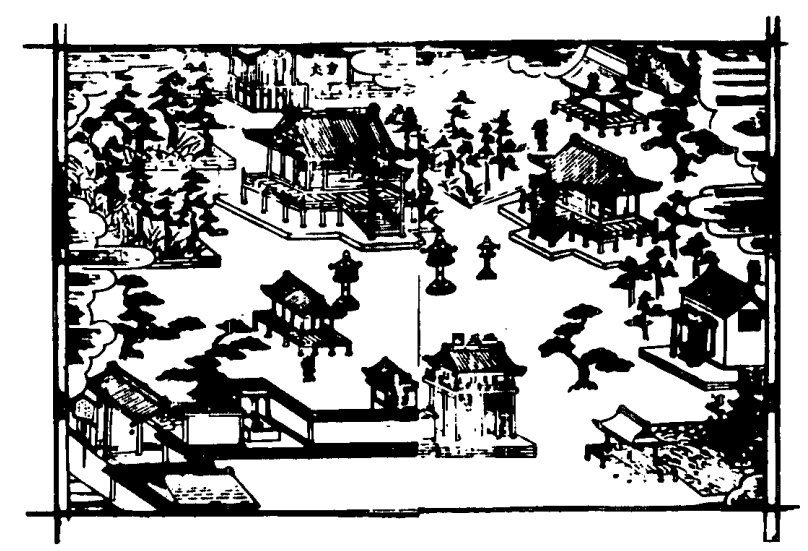

図一1 立本寺境内景観
東南に西面して祖師堂，西南に東面して刹堂が鼎立して 配され, 釈迦堂の背後に方丈 (本院), 祖師堂の背後に 番神社が配されている。七面明神社は表門の正面にある 池の中に配されている。そして, 釈迦堂の正面には二王 門 (楼門) が配され，二王門を入った右側に経蔵，左側 に鐘楼が配されている。しかし，『山州名跡志』には二 王門が脱落しているが，記載もれであると考えられる。

主要堂宇たる釈迦堂を南面させ，その正面に二王門 (楼門) を配し, 釈迦堂に向かって右側に祖師堂, 左側 に刹堂を配している京都日蓮宗本山寺院は本图寺 (京都 市下京区当時 $)^{10)}$, 頂妙寺 (京都市左京区) に見ること ができる。

この主要堂宇の配置の要因は, 前述の日朗門流相伝の 日経 (1473 歾) 記『御本尊口伝面授私』にある「本地' 文字二約”」, すなわち日蓮書写の文字曼茶羅の立体的配 座に則って, 大聖人 (日蓮) の本地を上行菩薩とする意 加, 釈迦堂の前方, 左側に御影堂 (祖師堂), 右側に 刹堂を配したものと考えられる。この左右の関係は「仏 の方より云ふ時の方角」である。

そして, 刹堂が中枢伽藍の主要堂宇に配された理由は, 日蓮の守護神のなかでも十羅刹女は極めて重要な地位に おかれており ${ }^{111}$ ，京都日蓮宗一致派においては ${ }^{121}$ ，応永 25 年 (1418) の妙顕寺の『起請文事』等に「法華経中 三宝, 十羅刹女, 三十番神, 抹五代祖師」范之古り, 当 時起請文に十羅刹女を請することが通例となったほ よ゙14)，十羅刹女を法華経の守護神とする風が一般的で あったがためと考えられる。

その後, 立本寺は宝永 5 年（1708）3月に類焼し, 現 在地内野に移転している。

『本化別頭仏祖統記』に「京兆立本寺二十四代日涊上 人伝」に「宝永五年戊子洛中失㫐火”立本寺モ亦鳥有トナル

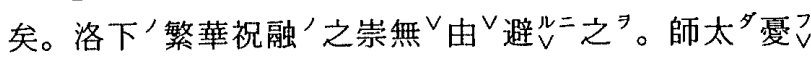

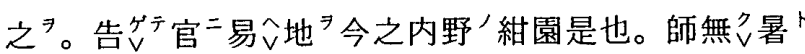

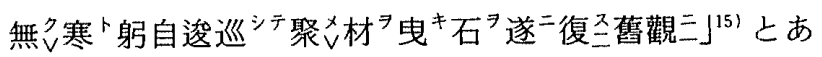
り，第 24 代日忍 (1724 歿) の代に再興されている。

前地京極今出川で類焼を免れた堂宇は移築され再建さ れているが，その堂宇は明治年間記『本坊及塔中建物明 細表』によると次のとうりである。

一. 祖師堂 宝永五戊子年再建 梁行七間半 桁行八間

一. 開祖廟 宝永五戊子年再建 梁行一間四尺五寸 桁行一 間半

一. 鐘楼堂 宝永五戌子年再建 梁行二間 析行二間

一. 本堂前井戸屋形 宝永五戊子年再建 梁行-一間 析行一 間

一. 経蔵 宝永五戊子年再建 梁行三間一尺五寸四分 析行 三間一尺五寸四分

であっだ6!。

その後, 同書によると元文 4 年 (1739) に鎮守堂, 宝 暦 5 年 (1755) には梁行 18 間, 桁行 13 間半の本堂, 安 
永 7 年 (1778) には明き 3 間の表門, 行者部屋, 門番部 屋が再建されている。

内野における伽藍配置は宝暦 4 年 (1754) 脱稿の『山 城名跡巡行志』に

門 東向又東西裏門二所アリ。

本堂 南向。

祖堂刹堂 在”堂前東西二。

七面 在”-祖堂南_。

番神'㗈 同 ${ }^{17}$ 。

とあり，そして，寛政元年 (1789）の「立本寺伽藍配置 図」 ${ }^{18)}$ (図一2）と天明 7 年 (1787) 刊の『都名所図会拾 遺』に所収されている「立本寺境内景観」 ${ }^{19)}$ (図一-3)に よって知ることができる。

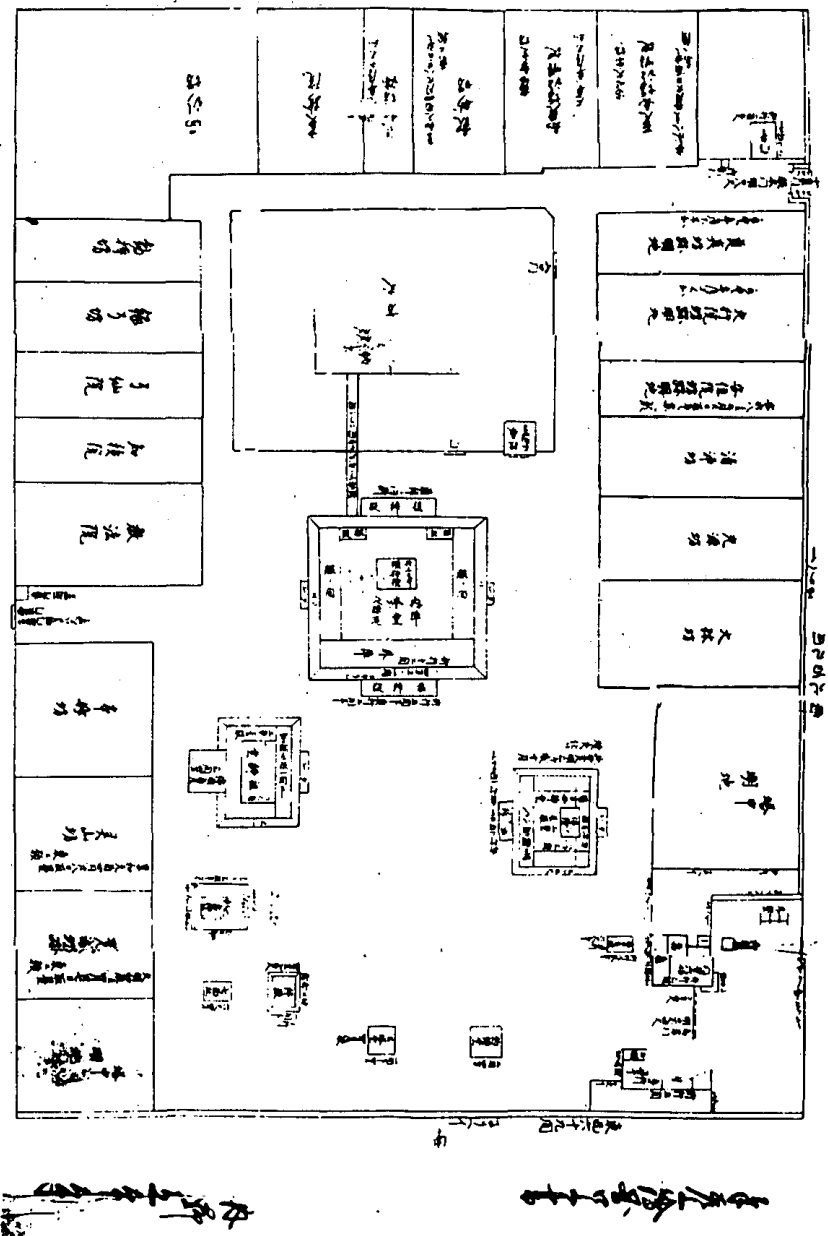

図一2 立本寺伽藍配置図

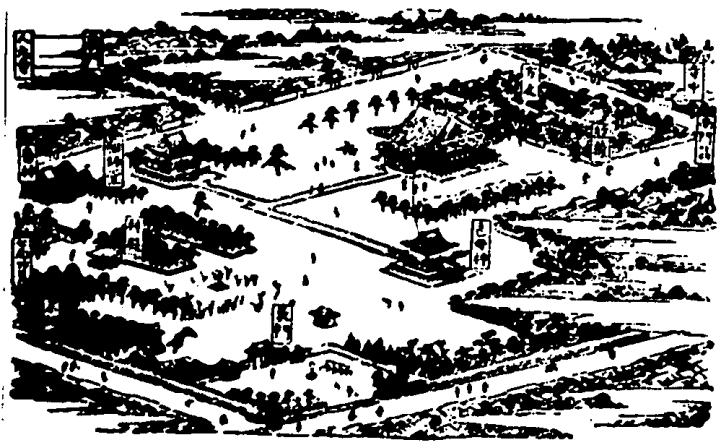

図一3 立本寺境内景観
寛政元年（1789）の「立本寺伽藍配置図」には本堂に ついて次のように記載されている。

一. 本堂 析行拾式間 梁行拾壱間 前拝後拝共 桁行五間 半奥江武間半宛有之' 惣躰柫形式手先組物二重垂 木. 仏壇之上小組·折上天井 内陣格天井板違 其外妻入母屋并前後拝共枰形蟇股等彫物有之

としている。前述の「本坊及塔中建物明細表」によると 祖師堂の規模は梁行 7 間半, 桁行 8 間, 刹堂は梁行 6 間 半, 析行 6 間半亡あり，本堂 (釈迦堂) の規模が最も大 きく，中心的堂宇としての性格が強かったものと考えら れる。また，同配置図に「当寺境内建物右絵図之通有来 候処鬼子母神堂儀者天明三卯年十月狫失仕候」とあり； 天明 3 年 (1783) に鬼子母神堂は焼失している。そして, 同書によると刹堂（鬼子母神堂）は文化 8 年（1811）に 再建されている。

前地京極今出川の伽藍配置と異なっていることは, 京 極今出川当時は寺地の西側の京極通に向かって表門を設 けていたが，内野に移転後は寺地の東，南北に走る七本 松通に向けて表門を構え，二王門（楼門）は配されてい ない。そして, 祖師堂と刹堂の位置が入れ替っているこ とである。

内野において二王門（楼門）を配さない理由は不明で あるが, 妙覚寺 (京都市上京区)の場合, 元禄 16 年 (1703) の『二王門再興帳序』によると, 檀越の助力も減って, 伽藍の修理もできないために二王門（楼門）は元禄 16 年より 42 年も前にたたんでいたが，「二王門ノスタレル コトヨ都鄙門流ノ真俗等ナゲキ寄場二不三相応一ョシ 諸人参詣シテハロズサミトス故二」」201 と二王門 (楼門) が再興されており，二王門（楼門）は重要な加藍の一つ であった。

しかし, 立本寺の場合, 前地京極今出川では二王門(楼 門)の軸線上に本堂 (觅迦堂) が位置する伽藍配置であっ たが，内野に移転後には二王門（楼門）は再建されず， 軸線が崩れ，表門が正門たる二王門（楼門）を兼ねるに 至っている。

そして, 刹堂は鬼子母神堂と改称されているが，その 理由は，近世に至って布教の手段として祈嚋法が飛躍的 な発展を示し，祈譸本尊として鬼子母神が定められ ${ }^{211}$, 十羅刹女より鬼子母神が主位となったがためと考えられ る。

日蓮書写の文字曼茶羅では, 正面に向かって左側に十 羅刹女, 右側に鬼子母神が勧請されていることから, 鬼 子母神堂を右側に配したと考えられる。

内野に移転後, 祖師堂と鬼子母神堂の配置替えがなさ れた理由は，二王門（楼門）が再建されなかったこと， そして, 守護神が十羅刹女から鬼子母神へと変換えされ たがためと考えられる22)。 


\section{3. 妙満寺における主要堂宇と配置}

妙満寺は永徳元年 (1381) に日什 (1392 歿) によっ て開創, 翌 2 年 (1392) に天王寺屋通妙から屋敷地を奇 進されて,ここに草庵を構えた。そして, 康応元年 (1389) に室町の草庵を妙塔山妙満寺と号した。その後, 錦小路, 東洞院に位置していたが, 天文 5 年 (1536) の天文法華 の乱によって焼失し，天文 16 年（1547）に綾小路堀川 西に再建された。天正 11 年(1583)頃豊臣秀吉の命によっ て寺町二条下町に移転させられている23)。

寺町二条における伽藍配置は延宝 6 年（1678）6月の 「美濃守様御本陣 妙満寺絵図」24) (図一4)によって知 ることができる。なお，この妙満寺絵図より「妙満寺主 要堂宇配置関係図」25)（図一5）を作製した。

そして, 元禄 15 年 (1702) 脱稿の『山州名跡志』に

門`西向

堂”南面”リ。

祖師堂”在”堂前三, 西面邓。

番神”社”在”堂”西三, 南面 ${ }^{226) 。}$

とある。

妙満寺の寺地は京極通（現在の寺町通）の東側に位置 し，東側に向けて表門があり，二王門（楼門）は設けら れていない。本堂（釈迦堂）は南面し，釈迦堂の東南の 位置に西面する高祖堂（祖師堂）が配され，釈迦堂の西 側に番神社と同择殿，同鳥居が配されている。そして， 番神社の鳥居の西側に三光堂が配されている。しかし， 刹堂 (鬼子母神堂) は配されていない。

前述の「美濃守様御本陣＼cjkstart妙満寺絵図」によれば中枢 伽藍の主要堂宇の規模は

一. 本堂正面 5 間 奥行き 7 間 前看 3 間 後看 1 間

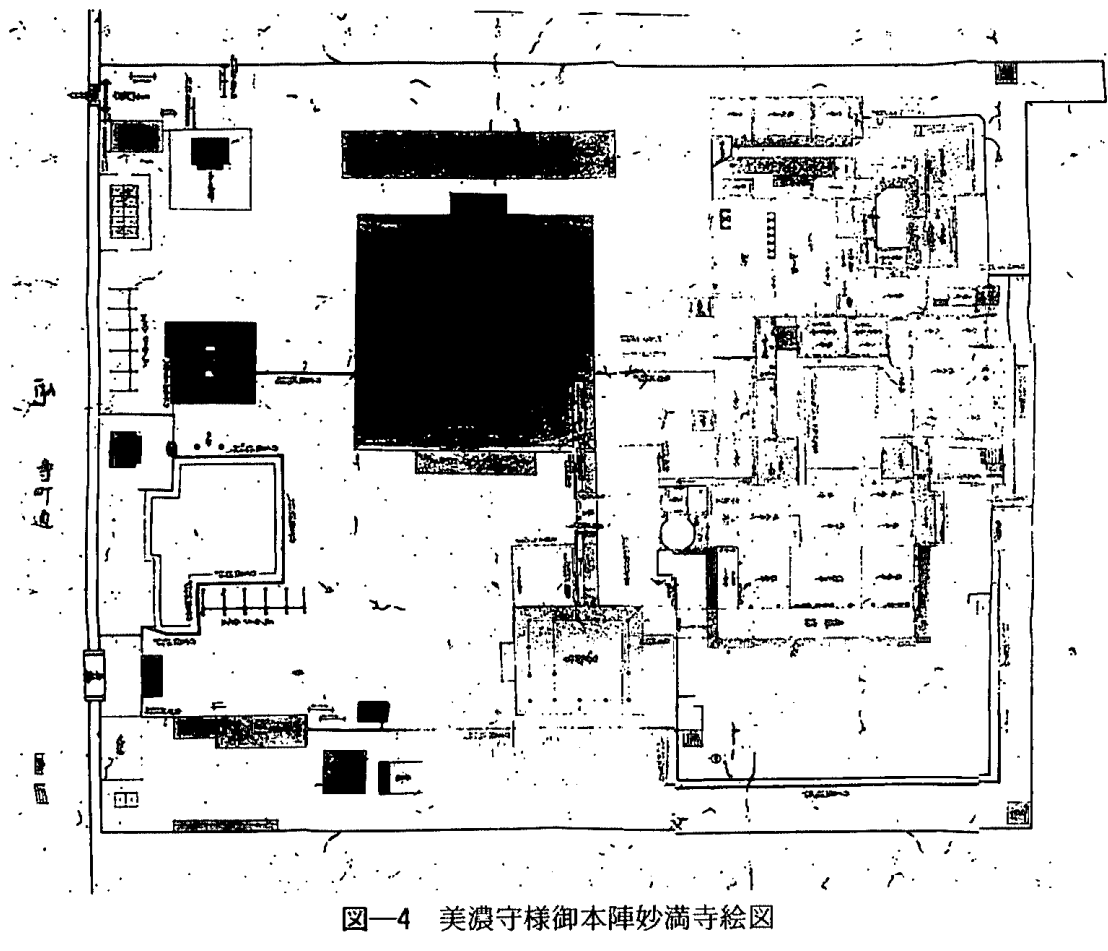

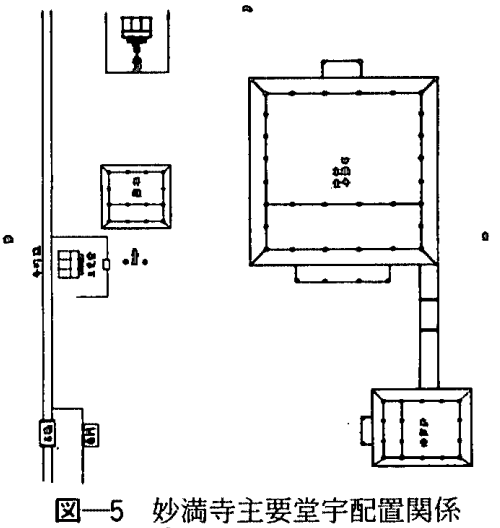

一. 高祖堂（祖師堂） 正面 3 間 奥行き 4 間 前拝 1 間

一. 番神社择殿 正面 3 間 奥行き 3 間

とあり, 本堂 (釈迦堂) の規模は高祖堂（祖師堂）より 大きく, 中心的堂宇としての性格が強かったものと考え られる。そして, 番神社と三光堂は, ほડ゙同規模に描か れている。しかし, 番神社抪殿は正面 3 間，奥行き 3 間 と規模は大きい。

中枢伽藍の主要堂宇たる釈迦堂は南面し, 釈迦堂に向 かって右側に高祖堂（祖師堂）を配することは，前述の 立本寺の伽藍配置と同様に日蓮書写の文字曼余羅の立体 的配座に則って配されたものと考えられる。

しかし，立本寺の伽藍配置と異なるところは，守護神 堂である。立本寺の守護神堂は刹堂 (鬼子母神堂)であっ たが，日蓮宗勝劣派に属する初期妙満寺においては三光 堂であったと考えられる。

. 三光堂が中枢伽藍の主要堂宇となった理由比次のよう に考えられる。

日蓮の身延山での生活は日朝（1500 歾）の『元祖化 導記』によれば, 早旦（早朝）に屿持 仏堂において勤経をなし，その後，日 天の御前において方便品, 寿量品の要 品を誦し，日中には法門談義をおこな い，日夕にも勤経をおこなっている。 早旦 (早朝)における日天の御前の勤 経，すなわち諸天善神信仰がすでにと り入れられていた27)。

宝徳元年（1449）日㕡記 『日什聖人 朝夕勤行掟之事』に「亦二座目“天” 勤”時 ${ }^{281}$ とあり，妙満寺開祖日什も 天の勤めとして継承している。

この諸天善神信仰の場が，三光堂へ と発展し，中枢伽藍の主要堂宇となっ たと考えられる299。

滝谷妙成寺 (石川県羽咋市滝谷) の 「妙成寺境内配置図 ${ }^{301}$ （図一6）によ ると，中央に南面して本堂（釈迦堂）, 本堂に向かって左側に鎮守堂（三光 


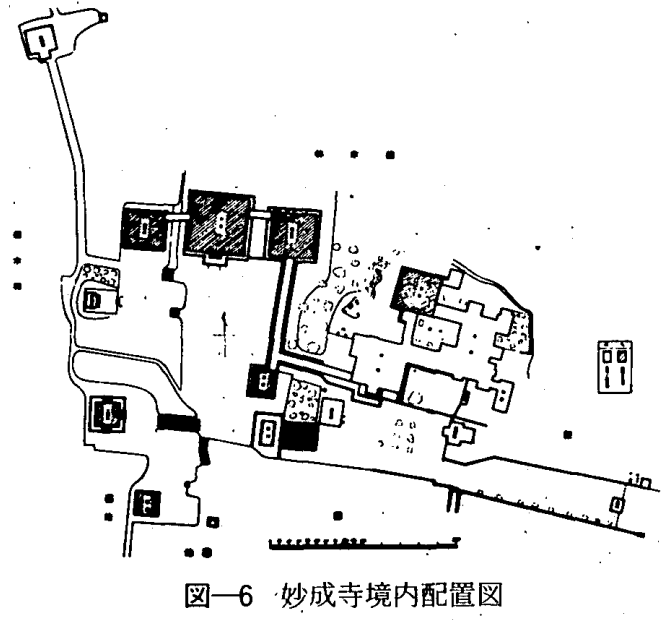

堂), 右側に開山堂（祖師堂）が併置されている。中枢 伽藍の主要堂宇を併置する配置が妙満寺の祖型と考えら れる。しかし，市街地にある寺地には限度があることか ら, 釈迦堂, 祖師堂, 守護神堂 (三光堂) を鼎立させる 配置をとったものと考えられる。

しかし，日蓮宗の京都進出の端緒を開いた日像 $(1342$ 歾)によって, 日蓮の守護神とされていた天照, 八幡の 二神の観念と結合させた三十番神がとり入れられ，法華 神道として重視されるようになった。

承応 3 年 (1654) の真陽書「禁断義十巻』に

日蓮の時代に三十番神を勧請したることなし，今も関東の日 蓮宗の寺には多分番神を勧請せず，京都において日蓮喴後に 日蓮党談合して卅番神を立つと見えたり ${ }^{31)} ， \ldots \ldots .$.

とあり，また，貞教元年（1684）刊『雍州府志』に

日蓮宗寺院に悉くこれを勧請す，日蓮上人の時伊勢・八幡の 二神を雓請して法ヶ守謢神となし日像上人の時三十社の神を 勧請して一月三十日のうち一日ごとに守護神をおくく ${ }^{32) 。 ~}$

とあり, 京都日蓮宗本山寺院の内, 要法寺, 寂光寺を除 いた全本山寺院に三十番神社が建立されている。

日蓮宗勝劣派に属する本興寺 (尼崎市開明町) の場合, 天和 3 年 (1683) 以前のものとされる「本興寺伽藍配置 図」33) (図一7)によると本堂 (哷迦堂) は南面し, 本堂 に向かって右側に祖師堂, 左側に鐘楼堂が鼎立し，鐘楼 堂の南側に三光堂と同遅殿が配され，三光堂は中枢伽藍 の主要堂宇に近い位置に配されている。三光堂内には中 央に三十番神, 左側に日天・旺 - 明星, 右側に大黒天, 鬼子母神が安置されており，その中心は三十番神となっ ているが，その堂宇は三光堂と呼称されている34。この ことから推察して, 日蓮宗勝劣派寺院の場合，ある時期 より，日天・月天・明星の三光天は三十番神に包含され るようになったものと考えられる。

妙満寺の場合も，ある時期より三光堂より番神社の方 が重要視されるようになり, 番神社は本堂 (䣋迦堂)の 西側に配され，番神社遅殿は正面 3 間，奥行き 3 間の規 模となり, 三光堂は形骸化したものと考えられる。そし

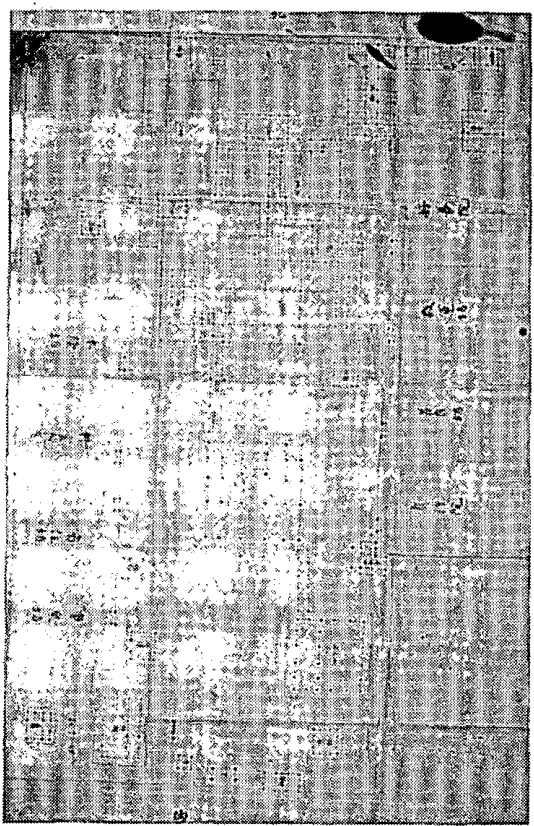

図一7 本興寺伽藍配置図

て, 中枢伽藍の主要堂宇たる釈迦堂, 祖師堂, 三光堂が 鼎立する配置が崩れたものと考えられる。

その後, 宝永 5 年 (1708)に油小路より出た失火によっ て類焼している。その後の伽藍配置は「妙満寺伽藍配置 図 ${ }^{35)}$ (図一8) によると, 中枢伽藍の主要堂宇の配置は 類焼以前と同梯であるが, 本堂 (䣋迦堂) の裏手に太鼓 堂が設けられ，祖師堂の奥行きは 5 間となり， 1 間程拡 大されている。そして，三光堂は妙日堂と改称され，そ の規模は析行 3 尺 8 寸, 梁行 2 尺 2 寸となっている ${ }^{361}$ 。

\section{4. 妙蓮寺における主要堂宇と配置}

創立は永仁 3 年 (1295) 頃, 日像の教化をうけた五条 の酒屋, 柳屋仲興が延慶 2 年 (1309) 西洞院五条の屋敷 に庵を設けたことに始まり，妙法蓮華寺と号した。応永

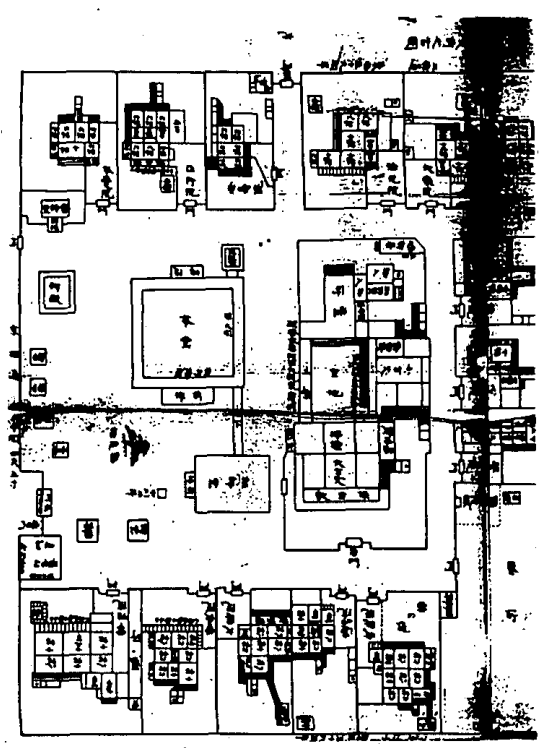

図一8 妙満寺伽藍配置図 
年中（1394 1427）に日慶, 日存, 日道, 日隆らが, こ の綾小路五条に草庵を構えていた。日慶（1478歾）は 日像の故地に因んで綾小路大宮に柳屋の外護で寺を再興 し, 妙法蓮華寺を略して妙蓮寺と号した。日慶は文明 5 年 (1473) 寺内に道輪寺学室を設け, 日忠 (1503 叒) を学頭に招請している。

天文 5 年 (1536) の天文法華の乱によって焼失し, 堺 の法華寺に一時退いたが, やがて天文 11 年（1542）帰 洛し，大宮西小路に再興した。天正年間（1573～91）に 豊臣秀吉の命によって現在地寺ノ内に移転させられ $た^{37)}$ 。

現在地に寺基を移した後,『妙蓮寺開闢再興略記』に「大 方丈は聚楽廃却の建物拝領して建る所。又慶長年中日源 上人の代，大仏殿建立の残木を拝領し本堂普請成就す。 上棟の当日は元和元年五月七日なり。夫より以来伽藍繁 栄し祖堂, 鐘楼, 三重宝塔, 大門, 浴室, 鼓楼, 宝蔵, 僧坊二十七院, 学室道輪寺等, 凡て蘭若に在所の堂塔巍々

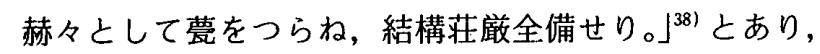
第 14 代日源（1622 歾）の代に本堂（釈迦堂）が建立さ れ，第 15 代日然 (1649 詔) の代に祖堂 (祖師堂) 等が 建立され伽藍が整備されている。

元禄 15 年 (1702) 脱稿の『山州名跡志』には

門`南向ナ゙。

堂乒”。

祖師堂`在”仁殿`西三, 南向ナ゙。

三重”塔”在”祖堂”南三, 東向ナリ。

番神’社”在”塔! 南三, 東向ざ。

鳥居モ同”。择殿モ同落9)。

とあり, 堂, すなわち釈迦堂は南面し, 祖師堂は釈迦堂 の西に南面し両堂は併置されている。三重の塔は祖師堂 の南に東面し, 番神社は三重の塔の南に東面して配され ている。しかし, 前述の妙満寺と同様に二王門（楼門） はなく, 刹堂は記載されていない。

この伽藍配㯰は寛延元年 (1748) の「妙蓮寺伽藍配置 図」40（図一9）とも合致する。

『境内諸堂建物』によると主要堂宇は次のようである。

一. 本堂 石燈籠一対本堂前有之 梁行十二間 析行十三間 高六丈 前择後遅 高欗确子口 祖師堂同断 右 日源上人御建立

一. 祖師堂 梁間八間 桁行七間二尺 高四丈六尺 前择三 間出 後垀同断 階前有之 柱総丸柱柝形虹梁海 老虹梁大瓶束幕股 絵様肘木三手先斗栱 四方唐 戸 四方高欄擬 内陣部戸 屋根瓦莫切妻破風

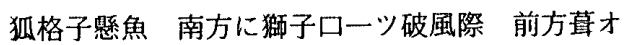
ロシ獅子ローツアリ 右日然上人御建立 天明焼 失後末再建

一. 三重宝塔 高サ五丈但シ九㫻マデ三間四方彩色ノ扇垂木 三手先斗栱 四方緑 屋根四方流 唐金九輪 右 建立細川丹波守内室瑞光院栄応妙宗禅尼 寛永七 年建立 ${ }^{41)}$

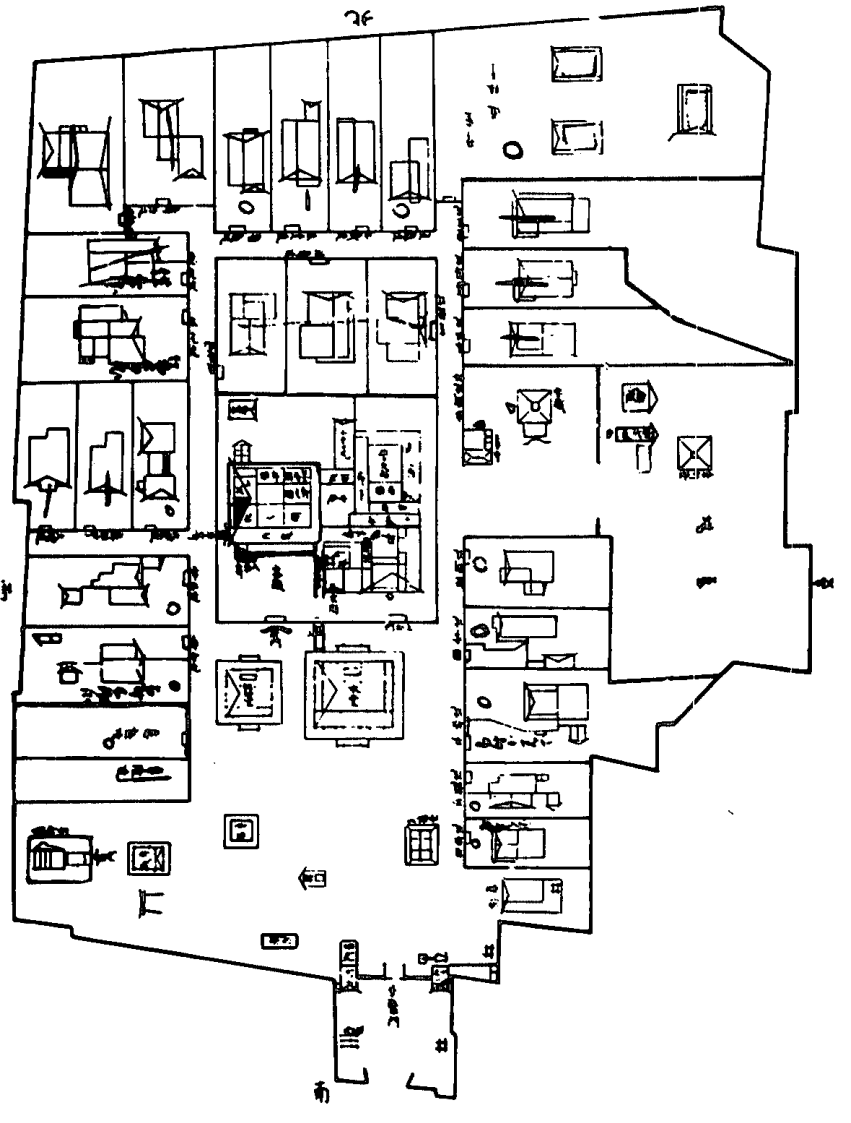

図一9 妙蓮寺伽藍配置図

とあり, 本堂 (釈迦堂) は桁行 13 間, 梁行 12 間, 高さ 6 丈で, 祖師堂は桁行 7 間 2 尺, 梁行 8 間, 高さ 4 丈 6 尺で积迦堂の規模の方が大きく，中心的堂宇としての性 格が強かったものと考えられるが, 祖師堂は「大瓶束蟇 股絵様肘木三手先斗栱」とあることから，贅をつくした つくりであったようである。

妙蓮寺の中枢伽藍の主要堂宇の配置は本堂（釈迦堂） の右側（仏の方より云了時の方角）に祖師堂垪置させ ているが, 前述の立本寺に妙満寺の祖師堂の位置とは逆 となっている。その理由は次のように考えられる。

京都本禅寺第 10 代日求 (1655 歿) の寬永 9 年 (1632) の『童矇懐覧集』の「以云高祖”御影Z奉 $\vee$ 坐背右方二事」 に

霊山説法”道場既“南向也, 故“諸堂悉”南向, 南向”時”右 來”乾也, 然”“高祖”所在”艮也, 御釉“云, 丑寅”廊二テ 可、待候「云云。

との質問に対して, 同書に

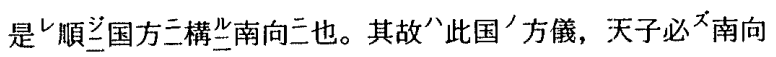
也。故二任气テ国方三命光法王シシテ南面セ也。

と, 伽藍配置は南面を基本としているが, 南面の場合, 同書に

南向”時“右座”乾也，然儿二高祖”所在”艮也，御积二云，丑 宙”廊“テ可、待候「云云。

と, 高祖（日蓮）の所在は丑寅 (北東) とされているが, 右座は乾 (北西) の方角になってしまう。したがって同 書に 


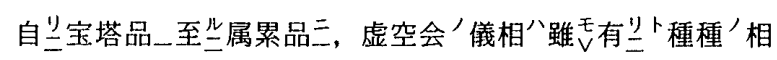
伝_, 任芫元祖”掟三堅”西面卜習〉也42)。

と, 南面の場合でも虚空会の儀相に順じ西向きを基に, 高祖（日蓮）の所在は右側であるとしている。

この記述は高祖（日蓮）の御影の安置についてのもの であるが，妙蓮寺の祖師堂を右側（仏の方より云ふ時の 方角）に配した理由は, 高祖（日蓮）の所在を五寅（北 東）に配することを配慮したがためと考えられる。

京都妙覚寺, 要法寺のように祖師堂の規模を釈迦堂よ り大きくすることはなかったものの ${ }^{43)}$, 祖師堂の位置を 重要視していたと考えられる ${ }^{44)}$ 。そして, 虚空会の宝塔 を意味する三重宝塔を祖師堂の前方に東面して配してい る。

その後, 享保 15 年 (1730) に本堂, 大門を残すほか, ほとんどの堂宇を焼失している。そして, 天明 8 年 (1788) の大火でも類焼している。焼失後の寛政 2 年 (1790) に は 12 間四面の仮本堂が再建されているが, 祖師堂は再 建されていない(5)。

\section{まとめ}

京都日蓮宗 16 箇本山寺院の内, 妙覚寺, 要法寺を除 いた全本山寺院において釈迦堂が中心的堂宇としての性 格が強く, 釈迦堂中心の伽藍配置となっている。また, 釈迦堂と祖師堂を配した 9 箇本山寺院が釈迦堂を右側, 祖師堂を左側 (仏の方上り云ふ時の方角) に配している。 しかし, 妙蓮寺と本隆寺の 2 䇢本山寺院は, その逆に 配している。

そして，日像によってとり入れられた三十番神信仰は 三十番神社として要法寺, 寂光寺を除いた全本山寺院に 建立されている。

一. 立本寺は文禄 3 年 (1594) に京極今出川に寺基を 動かしている。この地における中枢伽藍の主要堂宇の配 置は釈泇堂を南面させ, その前方東南に西面して祖師堂, 西南に東面して刹堂を鼎立して配している。この配置は 日蓮書写の文字曼余羅の立体的配座に則って配されたと 考えられる。

その後, 宝永 5 年 (1708) に類焼し, 内野に移転して いる。この地における主要堂宇の配置は, 祖師堂と刹堂 の位置が逆となっており, 刹堂は鬼子母神堂と改称され ている。

この要因は, 二王門 (楼門) が再建されなかったこと, そして, 守護神が十羅刹女から鬼子母神へと変換えされ たがためと考えられる。

一. 妙满寺の中枢伽藍の主要堂宇の配置は, 釈迦堂が 南面し, 高祖堂 (祖師堂) を左側（仏の方上り云ふ時の 方角）に配されているが, 立本寺の配置と同様に日蓮書 写の文字曼茶羅の立体的配座に則って配されたものと考 えられる。
そして, 釈迦堂に向かって左側に番神社, 同拝殿, 鳥 居が配され，鳥居の西側に三光堂が配されている。

日蓮宗一致派に属する立本寺の主要堂宇の配置と異な るところは, 守護神堂である。立本寺では刹堂（鬼子母 神堂) であったが, 日蓮宗勝劣派に属する初期妙満寺で は三光堂であったと推察される。

その後, 三光堂の主体である日天・月天・明星の三光 天は三十番神に包含され, 三光堂は形骸化したものと考 えられる。

そして, 中枢伽藍の主要堂宇たる釈迦堂, ‘祖師堂, 三 光堂が鼎立する配置が崩れたものと考えられる。

一. 妙蓮寺の中枢伽藍の主要堂宇の配置は, 釈迦堂が 南面し, 祖師堂が右側 (仏の方より云了時の方角) に併 置されている。その理由は高祖 (日蓮) の所在を丑寅 (北 東）に配することを配慮したがためと考えられる。

このことは京都妙覚寺, 要法寺のように祖師堂の規模 を釈迦堂より大きくすることはなかったものの, 祖師堂 を重要視していたがためと考えられる。

\section{註 記}

1) 櫻井敏雄：鎌倉新仏教仏堂平面の成立と系譜に関する研 究, 東京大学学位請求論文, pp. $387 \sim 408$, 昭和 52 年 8 月

2）拙稿：近世京都日蓮宗妙顕寺,妙覚寺, 要法寺の伽藍配置, 日本建築学会計画系論文報告集, 第 402 号, pp. 119 126, 1988 年 8 月

3)「妙本寺文書」, 堀日享編「富士宗学要集】第 2 巻「相伝・ 信条部」p. 299, 1975 年

4）「本尊論資料】第武編諸山相伝, p. 118 , 昭和 16 年, 身延 山専門学校出版。

5）「日蓮宗事典」, 東京堂, p. 743 , 昭和 56 年

6)【本満寺文書」, 梅木正雄「本化別頭仏祖統記」, p. 432, 昭和 55 年, 本満寺刊。この書は身延山久遠寺第 36 代日 潮 (1748 歿) 著。

7）前揭書「日蓮宗事典】，p.743。

8）「立本寺境内景観」,【新編法華霊場記】巻第二所収。本書 は天和元年 (1681) から貞享 2 年 (1685) にかけて編ま れたもので, 貞享 3 年 (1686) 版本として出版された。

9)「山州名跡志」巻之二十, (「新修京都叢書】第 19 巻, p. 231) 光彩社, 昭和 43 年。開版は正徳元年 (1771) であるが, 「山州名跡志序」は元禄 15 年 (1702) に書かれているこ とからこの年には脱稿していたものと考えられる。

10）前揭書, 櫻井敏雄 鎌倉新仏教仏堂平面の成立と系譜に 関する研究」，p. 397 によれば，本圆寺（京都市下京区当 時) の二王門 (西面) の位置は不自然で, 天正 19 年 (1591) に南の二町を本願寺に譲った時に二王門は致し方なく西 側に移された可能性があろうと指摘されている。このこ とから本图寺の二王門の位置は頂妙寺と同様に本堂（釈 迦堂) の正面に配されていたものと推察される。

11）拙稿：日蓮の教義・行儀と伽藍観，日本建築学会論文集, 第 343 号, p. 162 164, 昭和 59 年 9 月

12）日辇殆後，法華経の解釈において法華経二十八品の内， 前半十四品 (迹門) と後半十四品 (本門) に勝劣がない 
という立場をとっている側を日蓮宗一致派で、勝劣があ るという立場をとっている側を日蓮宗勝劣派と呼称して いる。

13）【妙影寺文書】, 立正大学日蓒教学研究所編【日蓮宗学全 畫」，第 19 巻「史伝旧記部」歴祖部第二之四，p.18，昭 和 49 年

14）前掲書「日蓮宗事典」, p. 947。

15）前揭書，梅木正雄「本化別頭仏祖統記】，p. 442。

16）【立本寺文書」, 立本寺所蔵。

17）【山城名跡巡行志」第一, (「新修京都叢聙】第 10 巻, p. 50) 光彩社，昭和 43 年。

18）「立本寺伽藍配置図」, 立本寺所蔵。寛政元年 (1789) の 作製，大きさ綐 $34 \mathrm{~cm}$ ，横 $52 \mathrm{~cm}$ 。

19）「立本寺境内景観」,「都名所図会拾遗」巻一，([新修京都 鋠書」第 12 巻, p. 29) 光彩社, 昭和 43 年

20）「妙覚寺文書」, 妙覚寺所蔵。櫻井敏雄「洛中法華宗本山 妙覚寺の伽藍と遗構」（「近畿大学理工学部研究報告」第 12 号, pp. $37 \sim 38$ 所収, 昭和 52 年 3 月)。

21）前掲書，旧蓮宗事典】，p. 58。

22）前掲書，「日蓒宗事典」，p. 57。

23）前揭書, 「日蓮宗事典」, p. 733。

24）【美濃守様御本陣妙満寺絵図」，京都府立総合資料館所 蔵。延宝 6 年 (1678) の作製, 大きさ縦 $39 \mathrm{~cm}$, 横 $50 \mathrm{~cm}$ 。 この絵図には, 本堂袈に本陣用の馬屋と馬取部屋と表門 脇と番神社择殿西側に馬つなぎが書き入れられている。

25）「妙满寺主要堂宇配置関係図」, 「美濃守様御本陣妙満寺絵 図」は不鮮明なところがあるで，同絵図より中枢伽藍の 主要堂宇を起した。

26）前揭寒, 【山州名跡志」巻之二十, (『新修京都叢書】第 19 巻, p. 237 。

27）拙稿：日蓮の教義・行儀と伽藍観，日本建築学会論文報 告集, 第 343 号, pp. 162 164, 昭和 59 年 9 月

28）【妙満寺文書】, 前揭書「日薄宗学全書】, 第 5 巻「顕本法 華宗部」, p. 118。

29）拙稿：中世における日蓮宗富士門流の伽藍と建築 その 1, 日本建築学会諭文報告集，第 331 号，pp. 123 129, 昭和 58 年 9 月

30）「妙成寺境内配置図」，「重要文化財妙成寺開山堂及鐘楼修 理工事報告書」, 昭和 29 年 11 月所収。

31）宮崎英修「日蒲宗の守護神」，平楽寺書店， p. 93，1977 年
32）【雍州府志」第二，(「新修京都叢書】第 3 巻, p. 236）光 彩社, 昭和 43 年

33）「本興寺加藍配置図」, 本興寺所蔵。天和 3 年 (1683) 以 前のもの, 大きさ縦 $180 \mathrm{~cm}$, 横 $100 \mathrm{~cm}$ 。

34）【尼崎市史』第 10 巻, p. 675,1974 年

35）「妙満寺伽藍配置図」, 妙満寺所蔵。大きさ縦 $110 \mathrm{~cm}$, 横 $80 \mathrm{~cm}$ ，この伽藍配置図には「天明焼失前之古図」と記さ れている。

36）山根日東「妙満寺概観」，p. 14, 昭和 16 年 1 月

37）前掲書，「日蓮宗事典】，p.735。

38）【妙蓮寺史】，妙蓮寺刊，p. 67 ，昭和 57 年

39）前揭畫，「山州名跡志」巻之二十一，([新修京都橖書」第 19 巻, p. 265 。

40）「妙蒲寺伽藍配置図」，妙蓮寺所蔵。寞延元年（1748）の 作製，大きさ縦 $150 \mathrm{~cm}$ ，横 $110 \mathrm{~cm}$ 。

41）妙蓮寺所蔵。この書は往昔の記録を集めた『妙蓮寺記」(大 正 11 年 4 月腾写) に所収されている。

42）【本成寺文書】, 前揭書「日蓒宗学全書】, 第 7 卷「法華宗 部」, pp. 288 289。

43）拙稿：近世京都日蓮宗妙顁寺, 妙覚寺, 要法寺の伽藍配殖, 日本建築学会計画系論文報告集, 第 402 号, pp. 119 126, 1989 年 8 月。妙覚寺については, 前揭書, 櫻扑敏雄【鎌 倉新仏教仏堂平面の成立と系譜に関する研究」, p. 428 に 上れば，「寛永 6 年祖師堂建立の時点で本堂より大規模と なり，実質上の本堂の態をなしているように考えられる。」 と指摘されている。

44）拙稿：日蓮の教義・行儀と伽藍観，日本建築学会論文集， 第 343 号, p. 164。日我（1586 㱛）の「化儀秘決」に「本 尊の示書にも日蓮は左り, 書写の人は右, 去方間本尊堂 は左り, 御影堂は右, 御影堂は左り, 客殿己下は右なり」 とある。「本尊の示書」, すなわち文字曼茶羅には, 日蓮 の署名と花押が左り,「書写の人」, すなわち本山寺院の 歴代の買主は右に署名と花押を記している。これに則っ て本尊堂は左側, 御影堂は右側 (仏の方上り云了.時の方角) に配するか，また，御影堂を左側に配する場合は客殿己 下は右に配するとしている。この配置方法に則っている 本山寺院は大石寺, 重須本門寺があり, 御影堂（祖師堂） が重視されている。

45）前揭書，「日蓮宗事典」，p. 735。

(1990 年 8 月 3 日原稿受理, 1991 年 4 月 8 日採用決定) 